\title{
Evolution and Innovations of the National Neonatal and High Risk Screening Program in Costa Rica
}

\author{
Carlos de Céspedes*, Manuel Saborío, Rafael Trejos, Gabriela Abarca, \\ Avelino Sánchez \& Laura Rojas \\ National Newborn and High Risk Screening Program, Center for Prevention of Disabilities, National Children Hospital, San \\ José, Costa Rica. \\ * Consultant ad honorem
}

Received 02-VI-2004. Corrected 03-VIII-2004. Accepted 04-IX-2004.

\begin{abstract}
We present the evolution, organization and results of the National Neonatal and High Risk Screening Program in Costa Rica (PNT). This program has been working uninterruptedly for more than fourteen years. Costa Rica currently has a literacy rate of $95 \%$. To August 2004 the rate of infant mortality was 9.74 per 1000 births and to 2003, life expectancy was 76.3 years for men and 81.1 years for women. The control of infectious and parasitic diseases, as well as of severe malnutrition, has given room to a prevalence of chronic diseases with a pathology profile similar to that of a developed country. The clinical observation, mainly starting from early 70 s, of a growing number of patients with mental retardation and other disabilities caused by congenital hypothyroidism and hereditary metabolic diseases that could have been prevented in many cases with an early diagnosis and opportune treatment, led us to the decision to implement a systematically massive neonatal screening for these diseases. The presence of a single Public System of Social Security in Costa Rica, which currently includes from primary health care up to the hospitals of tertiary attention, with a single Children's Hospital for the whole country, as well as communication facilities, are factors that offered, in principle, favorable conditions for this effort, even for a developing country. To September 2004, 835,217 children have been screened. There is a coverage of $95.1 \%$ of the newborns in the country. Also to this date, 259 children with congenital hypothyroidism, 18 with phenylketonuria, 20 with the maple syrup disease, 30 with congenital adrenal hyperplasia and 10 with galactosemia have been detected, confirmed and treated, for a total of 337 children that were spared of mental retardation, other disabilities and even death. Massive neonatal screening for organic acidemias recently started in June of 2004. Cystic fibrosis is under a pilot study and the screening for hemoglobinopathies and toxoplasmosis is planned. The Center for Prevention of Disabilities, which started its functions on September 23, 2002, made feasible to integrate neonatal screening, high risk screening and diagnostic confirmation of the diseases now included in the national screening program as well as those to be added in the future. Rev. Biol. Trop. 52(3): 451-466. Epub 2004 Dic 15.
\end{abstract}

Key words: Newborn screening, high risk, disabilities, inherited metabolic diseases, congenital hypothyroidism.

Palabras clave: Tamizaje neonatal, alto riesgo, discapacidades, enfermedades metabólicas hereditarias, hipertirodismo congénito.

Costa Rica, since abolishing the army officially in 1949, has invested its scarce socioeconomic resources fundamentally in education and health. By doing this, the literacy rate is currently $95 \%$ and by the end of the 70s, Costa Rica presents a pathology profile characteristic of a developed country. To August 2004 the rate of infant mortality was 9.74 per 1000 births and to 2003, life expectancy was 76.3 years for men and 81.1 years for 
women (INEC 2004). In fact, with the control of diarrhea and other infectious illnesses, parasitosis and severe malnutrition (de Céspedes 1991), chronic diseases such as cardiovascular disorders, cancer, congenital malformations, metabolic diseases and psychiatric disorders (de Céspedes et al. 1996b) started to emerge. Public health actions such as the provision of potable water, massive vaccination programs and the universal access to essential health services, are the fundamental base on which this epidemiologic transition has developed. Such actions, although relatively simple must be maintained in order to avoid any setbacks. However, we should go much further in the case of chronic diseases, being that their prevention is much more complex and they require approaches based on new technologies.

The prevention of disease, together with the promotion of health and medical care, are the essential components of health policy; prevention is a way of saving in human suffering as well as health expenses. The prevention of disease, regardless of the limitations pointed out by some authors regarding the classification (Downie et al. 1996), can be considered in three levels:

- Primary prevention: avoid the presence of the disease

- Secondary prevention: early detection and timely treatment of a disease in order to avoid or to minimize its consequences

- Tertiary prevention: Rehabilitation

Screening is a health test in an asymptomatic population; it can be massive, being applied in this case to the whole population or selective, also called "high risk screening". A more informative definition of screening is: "the application of procedures to populations or population groups, with the aim of classifying them into two groups: one with high probability of being affected by fatal conditions or disabilities and the other group with low probability of presenting disease under the same conditions. The group detected as with high probability is referred to the health services for conclusive diagnosis and follow up". (CCSS 2001-2006).

Screening, to be scientifically and ethically valid, should fulfill a series of requirements, such as the availability of a reliable low cost test, the guarantee of a prompt diagnostic decision in the detected individuals, followed by proper treatment and follow up of the confirmed patients (AAP 2000). Up to now the only successful example of massive screening is that of treatable congenital disorders, such as hypothyroidism and the inherited metabolic diseases or inborn errors of metabolism, which we discuss in this paper (Levy and Albers 2000).

The high risk is applied fundamentally to those with a family history of diseases like coronary artery disease, epidemiologic situations such as AIDS in homosexuals or non specific clinical signs in the case of some of the inherited metabolic diseases, where massive screening cannot yet be applied (vide infra).

The Genetic Revolution, prompted by the development of technology for recombination of DNA or genetic engineering and the progress of the Human Genome Project (HGP), gives to us the opportunity to practice medicine with a preventive focus, identifying early risk factors for common diseases such as cardiovascular, autoimmune, diabetes, cancer and psychiatric disorders. Practically all of these present genetic components which, when they interact with specific environmental factors contribute to a higher or smaller degree in their causation. In accordance with this new Genetic Paradigm of Health and Disease, the prevention of the most common diseases in the adult should begin at early ages (Scriver et al. 1980).

The medicine of the XXIst century will therefore be based, more and more upon the prediction by means of screening, prevention and individualized intervention (Guttmacher and Collins 2002). With this approach it will eventually be possible to avoid or to decrease the come forth of many of those diseases, or at least to minimize their consequences through modifications in lifestyle, diet or by means of novel therapeutic interventions derived from 
the HGP. These interventions will be more effective as the physiopathology at the cellular level becomes better known, thus identifying specific alterations at the molecular level which will finally allow for the design of drugs that may revert these alterations. Given an individual genetic profile, obtained by DNA markers like Single Nucleotide Polymorphisms (SNPs), identified by microchips (Guttmacher and Collins 2002), it will be possible to individualize the treatment with drugs for each patient, thereby achieving better effectiveness and at the same time eliminating or diminishing the undesirable secondary effects, which is the goal of pharmacogenomics (Collins 1999). Gene therapy, or the introduction of a normal gene to substitute the function of an affected homologous gene, is being object of intense investigation from the basic up to the clinical level. With advances in the clinical application of this revolutionary way of treatment, curative in principle, screening can then be expanded to a growing number of diseases that are not presently included in screening programs due to the ethical limitation of currently not being able to offer treatment to an individual diagnosed with an incurable disease.

Kaback (Kaback 2001) meetly classifies the applications of HGP to screening in three types:

1. Diagnosis of a disease in pre-symptomatic stage. Successful experience exists with this application in neonatal screening programs, which is the subject of this paper. Although the benefit of screening for phenylketonuria, congenital hypothyroidism and others is accepted universally, controversy exists as for the ethics of the pre-symptomatic diagnosis of delayed start diseases such as Huntington's disease, which have no effective treatment.

2. Increased predisposition to develop a disease. The difference with the previous situation is that in this case the idea is to estimate the statistical probability in an individual to develop a disease that is still not present. This is one of the applications of the HGP that has created great expectations. There is currently open and intense debate as to the predictive value of DNA tests to identify individuals at risk of developing a disease such as breast or colon cancer, and looking further into the future, applied to diabetes mellitus, coronary artery disease, bipolar disease, Schizophrenia and Alzheimer's. The results, although hopeful, are not conclusive for the time being in most cases (Collins 1999).

3. Identification of individuals at risk of transmitting a hereditary disease. In this case tests are applied to young adults in order to search for biochemical alterations or mutations at the DNA level, which does not include their current or future health but instead bear the risk of being carriers of a hereditary disease and may thus transmit an active form of it to their descendents. This is what is classically known as genetic screening. Examples of this approach are the screening of heterozygotes in recessive disorders such as Tay Sachs's disease, the $\beta$-thalasemias and more recently cystic fibrosis. When identifying couples at risk, it is possible prevent an affected offspring by means of genetic counseling which includes parental consideration of prenatal diagnosis and abortion.

Our efforts to prevent disabilities through screening in Costa Rica can be put in perspective by adopting Kaback's classification. Our National Neonatal Screening Program corresponds entirely to point number 1 (secondary prevention) in the aforementioned classification. The Center for Prevention of Disabilities (vide infra) has been created with the mission to expanding and optimize the PNT, while at the same time to maintain the vision of projecting into the future as to the prevention of disease, inasmuch as the advances of the HGP and ethics will allow it (Point 2 or primary prevention). 
Point number 3 is not contemplated at the moment in Costa Rica as a public health program, due to bioethical, religious and legal considerations such as the prohibition of abortion.

\section{MASSIVE NEONATAL SCREENING}

The feasibility to carry out laboratory tests in a small blood sample able to be conserved for a long time in a filter paper (Dried Blood Spot or DBS), thanks to Robert Guthrie's pioneer work (Guthrie 1961) allowed the launching of programs of massive neonatal screening (MNS). These programs were implemented in developed countries in the mid $60 \mathrm{~s}$ for phenylketonuria (PKU) with a test based on bacterial inhibition growth (BIA) developed by Guthrie himself for phenylalanine determination (Guthrie and Susi 1963) as well as for congenital hypothyroidism $(\mathrm{CH})$ by the mid 70 s, when the determination of thyroxin and thyroid stimulating hormone was implemented in the same "Guthrie card" (Dussault et al. 1975).

In Latin America national MNS programs exist in Brazil, Mexico, Chile, Cuba, Uruguay and Costa Rica. Partial programs have started in Argentina, Venezuela and Colombia (Anonymous 2001).

Besides PKU and $\mathrm{CH}$, other diseases are included in massive neonatal screening, depending on local epidemiological conditions and on available resources (Levy and Albers 2000). The introduction of mass spectrometry in tandem (MS/MS) (Levy 1998) and eventually the analysis of DNA (Zhang et al. 1994) open the possibility of expansion of MNS to a larger number of diseases.

The fundamental objective of MNS programs is the prevention of mental retardation, other disabilities like cataracts, developmental problems and even death, when detecting and treating patients early, ideally before one month of age.

Besides avoiding the moral cost that these diseases represent for the patient, their family and society in general, MNS programs avoid costs that arise out of misdirected and fruitless medical care, as well as special education, with a likely decrease of income of parents due to work limitations outside the home. In fact, a World Health Organization report points out that for each case detected in MNS programs which include $\mathrm{HC}$ and PKU, the health system saves around 100000 U.S. dollars (Bulyzhenkov 1991). In a study carried out by our group in the early 80 s, it was estimated that for each colón (local coin for Costa Rica) invested in a screening program such as the PNT, 5.1 colones are saved (Chavarría and de Céspedes 1981).

Pediatricians and other specialists acknowledge the decrease in effort, cost and especially anxiety brought on to family members and even physicians and other health personnel, when having an early diagnostic definition. This avoids consultations, hospitalizations, laboratory and cabinet exams, which may lead to late diagnosis thus causing irreparable damage, added to the distrust that these situations generate in the parents, further deteriorating the doctor-family relationship, so important in the follow up of a chronic disease (Dodge 1999).

\section{NATIONAL MASSIVE NEONATAL SCREENING PROGRAM IN COSTA RICA}

\section{Context}

The Costa Rican Board of Social Security (CCSS) is an autonomous governmental institution which centralizes the public hospitals and health centers of the country. The Ministry of Health shifted to have a rectory role. It has thus transferred the services of primary care to the CCSS, organized as Basic Teams of Integral Attention of Health (EBAIS) distributed around the entire country for a total of 822. It is also integrated by Clinics, Regional Hospitals and Hospitals of Tertiary Attention in San José, the capital, with a single specialized Children's Hospital. All of these are used as collection centers for newborn screening 
blood samples This CCSS facilities, together with phone, terrestrial and even air or marine communication facilities, in a territory of scarcely $52000 \mathrm{~km} 2$, with 4500000 inhabitants, offers indeed favorable conditions for the operation of an MNS program (Estado de la Nación 2001).

\section{Historical development of neonatal screening in Costa Rica}

Seeking to implement the PNT, our group in Costa Rica carried out several studies in patient populations at high risk of being affected by a inherited metabolic disease (IMD) (de Céspedes et al. 1983a, 1984) as well as pilot studies directed to implement massive neonatal screening all over the country (de Céspedes et al. 1983b, de Céspedes 1986). Thus, the National Massive Neonatal Screening Program (PNT) was launched officially in March of 1990 thanks to the economic support of the Board of Social Protection of San José (JPSSJ), complying with the Executive Decree $\mathrm{N}^{\mathrm{o}}$ 19504-S, published in La Gaceta of March 23, 1990. The CCSS approved the institutionalization of this Program by means of a Cooperation Agreement subscribed parallel to the CCSS, the Ministry of Health, the National Children's Hospital "Dr. Carlos Sáenz Herrera" (HNN) and the Costa Rican Association for Screening and Prevention of Disabilities in Children (ASTA). Initially, and until June of 1998, the Costa Rican Institute of Research and Teaching in Nutrition and Health (INCIENSA), adscript to the Ministry of Health also participated in this Agreement. Besides in that same year the Minister of Health issued a new decree, $\mathrm{N}^{\circ} 23931-\mathrm{S}$ which excluded INCIENSA (where the National Neonatal Screening Laboratory was operating) and transferred the administration of that Laboratory to ASTA. Shortly afterwards, the National Neonatal Screening Laboratory and the High Risk Screening Laboratory (founded in 1976 as the Division of Biochemistry of the Laboratory of Investigation of the HNN) were fused into one, now called the National
Laboratory of Neonatal and High Risk Screening or Central Screening Laboratory, finally established in the Center of Prevention of Disabilities of the HNN (vide infra)

The progress of the PNT has been reported in different publications, mainly national and international meetings (Casco et al. 1999, de Céspedes et al. 1995a, b, 1996a).

The diseases included uninterruptedly from the beginning of the Program in March of 1990 and during these past fourteen years, are: (1) Congenital Hypothyroidism (CH), (2) Phenylketonuria (PKU), and (3) Maple Syrup Disease (MSD).

After a pilot plan carried out between 1999 and 2000, the screening of the following diseases officially began in January of 2002: (1) Congenital Adrenal Hiperplasia (CAH), and (2) Galactosemias: Galactose-1-phosphate uridyl-transferase (GALT) Deficiency ("Classic" Galactosemia), and Galactokinase (GALK) Deficiency.

Furthermore, the donation of a tandem mass spectrometer (MS/MS), by the Japanese Agency of International Cooperation (JICA) allowed us to begin high risk screening for organic acids in January, 2004.

Thus, in June 2004 the PNT started massive screening for the following groups of disorders: (1) Organic Acidemias (OA) (e.g. Propionic Acidemia (PA), Methyl Malonic Academia (MMA)), and (2) Fatty Acid Oxidation Disorders (FAO) (e.g. Medium Chain Acyl-CoA Dehydrogenase Defficiency (MCAD)). Table 1 lists the specific disorders screened.

\section{Objectives of PNT}

The general objetives were 1.) To prevent mental retardation and other disabilities caused by IMD and related disorders. 2.) Initiate the development of services of Predictive Medicine in the Health System of Costa Rica, and 3.) To carry out scientific investigation applied to the continuous improvement of screening.

The Specific objectives were 1.) To detect and early diagnose newborns affected with 
TABLE 1

Disorders Included in the Screening Program in June, 2004

$\begin{array}{ll}\text { Disease } & \text { Analyte } \\ \text { MCAD } & \mathrm{C} 6, \mathrm{C} 8, \mathrm{C} 10: 1 \\ \text { VLCAD } & \mathrm{C} 14: 1, \mathrm{C} 16: 1, \mathrm{C} 14 \\ \text { LCAD } & \mathrm{C} 16, \mathrm{C} 18: 1 \\ \text { SCAD } & \mathrm{C} 4, \mathrm{C} 4 / \mathrm{C} 2, \mathrm{C} 4 / \mathrm{C} 3 \\ \text { CPT II } & \mathrm{C} 16, \mathrm{C} 18: 1 \\ \text { GA II } & \mathrm{C} 4, \mathrm{C} 5, \mathrm{C} 6, \mathrm{C} 5 / \mathrm{C} 3 \\ \text { PA } & \mathrm{C} 3, \mathrm{C} 3 / \mathrm{C} 2 \\ \text { GA I } & \mathrm{C} 5-\mathrm{DC} \\ \text { MMA } & \mathrm{C} 3, \mathrm{C} 3 / \mathrm{C} 2 \\ \text { IVA } & \mathrm{C} 5, \mathrm{C} 5 / \mathrm{C} 3 \\ 3 \text { MMC } & \mathrm{C} 5-\mathrm{OH} \\ \text { b-KT } & \mathrm{C} 5: 1, \mathrm{C} 5 \mathrm{OH} \\ \text { HMGCoA Lyase deficiency } & \mathrm{C} 5-\mathrm{OH}, \mathrm{C} 6 \mathrm{DC}\end{array}$

CH, PKU, MSD, CAH, GALK, GALT, OA and FAO. 2.) To provide opportune medical treatment and follow up to the affected children. 3.) To provide Genetic Counseling to affected families.

Our goal was to cover the entire newborn population in Costa Rica. Components of the program include: detection, diagnosis, treatment, follow up and genetic counseling.

\section{Operation of the program}

The sequential process of the PNT with the recently enumerated components, is summarized in the following flow chart (Fig. 1).

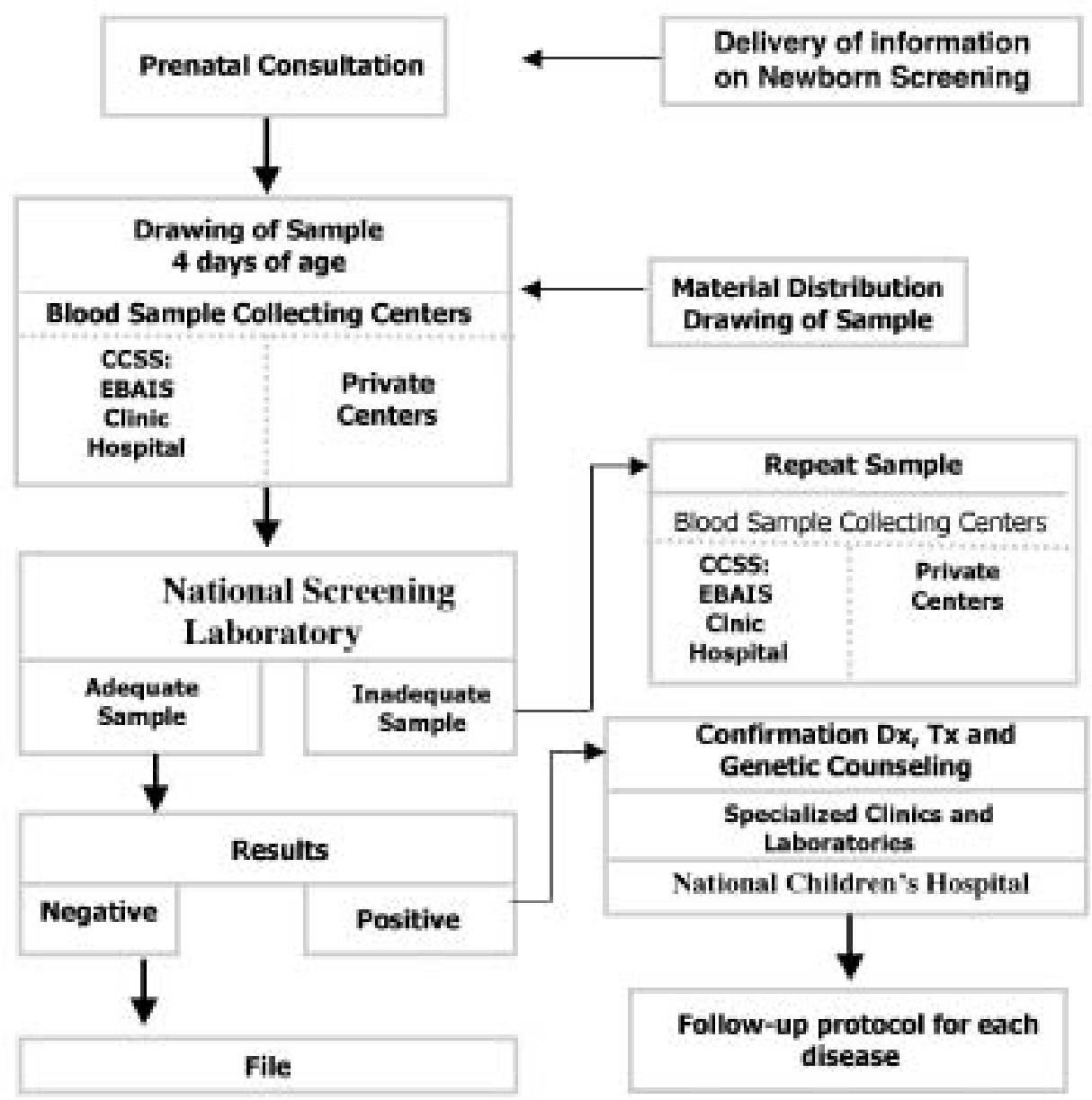

Fig. 1. The sequential process of the National Neonatal and High Risk Screening Program in Costa Rica. 
The entire screening process for the PNT runs as follows. From the prenatal clinic and/or in the nursery, an explanatory brochure is given to the mother or main caregiver, so that he/she brings the newborn at 4-7 days of age to the EBAIS or Clinic corresponding to their address. In the case of hospitalized children the sample is taken independently of their health condition. In accordance with the Decree, it is mandatory for the health personnel to draw the sample during those suitable days; the private physician's clinics and private clinical laboratories can carry out the blood sampling voluntarily and may not charge for the procedure. In the "Health Card" each child is provided with at birth, in the same page of the vaccination record, there is a box to register the taking of the "Metabolic Test". Once in the EBAIS or Clinic, a few drops of blood are drawn - by means of a heel prick procedure - which are then collected on a special filter paper (Schleicher and Schuell 903 ("Guthrie card"). At the same time, essential data of child and mother are entered in a form, most importantly the telephone number and current address for their location in the event of a positive result. In order to minimize the possibility of mixing samples up, the original form has the filter paper attached to its right end; both items share the same number and a bar code which allows for the samples to be automated in the reception system and coding. The original form is entered in the Program database; one of the two copies goes to the child's family and the other to the recollection center, respectively.
The filter paper with the dry blood sample is stable for a long time, which allows for it to be sent by mail. Most of the cards are taken directly to the PNT Lab by parents. An increasing number of samples are now being picked up at reception centers and delivered to the PNT by a courier called Express Mail Service (EMS) and a lesser number by the internal mail of the CCSS or by regular mail, these last two being the less efficient. The average transit time is 7 days, EMS being the most efficient (5 days). Samples are received at the National Laboratory of Neonatal and High Risk Screening currently occupying most of the building for the Center for Prevention of Disabilities (CPD). Through years of experience, we have observed that the necessary technical personnel's specialization, the registration process and the statistical control is feasible as long as the laboratory analyses are centralized. The personnel involved in the entire process is further motivated when the initial positive cases all remain centralized and can be taken care of in a single location.

\section{Laboratory Analyses}

Table 2 shows the diseases currently included in the PNT, the analytes measured in the "Dry Blood Spot" (DBS), the laboratory method used in each case and the cut off point to consider a result as positive. For each analyte a $3 \mathrm{~mm}$ (1/8 inch) disk is perforated out of the DBS. Every sample is analyzed in duplicate to ensure reliable results.

TABLE 2

Diseases included in the National Neonatal Screening Program in Costa Rica*

$\begin{array}{lccc}\text { Disease } & \text { Analyte } & \text { Method } & \text { Break point } \\ \text { Congenital Hypothyroidism } & & & \\ \text { Phenylketonuria } & \text { TSH } & \text { IFMA } & 16 \_U 1 / \mathrm{ml} \\ \text { Maple Syrup Disease } & \text { Phenylalanine } & \text { BIA } & 4 \mathrm{mg} / \mathrm{dl} \\ \text { Congenital Adrenal Hyperplasia }+ & \text { Leucine } & \text { BIA } & 4 \mathrm{mg} / \mathrm{dl} \\ \text { Galactosemia }+ & 17-\text { OHP } & \text { IFMA } & 20 \mathrm{ng} / \mathrm{ml} \\ & \text { Galactose } & \text { EFA } & 12.8 \mathrm{mg} / \mathrm{dl}\end{array}$

\footnotetext{
* See Table 1 for the most recently included diseases

+ Pilot Study 1999-2000. Starts officially in January 2002
} 
The initial laboratory tests for neonatal screening, include the determination of thyroid stimulating hormone (TSH) levels (AutoDELFIA hTSHl) and of the hormone 17hydroxyprogesterone (17-OHP) (AutoDELFIA 17-OH-Pl), both of which use an automated immunofluorometric method (IFMA) based on the technology Auto Dissociation Enhancement Lanthanide Fluorometric Immunoassay (AUTODELPHIA). The determination of the amino acids phenylalanine and leucine are carried out by the classic Guthrie's bacterial inhibition assay (BIA) (Guthrie et al. 1963). Galactose is measured by an enzymatic-fluorometric method (EFA) (Neonatal Galactose) Organic acids are measured in a Mass Spectrometer in Tandem (MS/MS), Micro mass, model Quattro micro. When the blood concentration of any of these substances is elevated above the pre-set limits (cut off point), the newborn is recalled for diagnostic confirmation. If affected, the child is enrolled for treatment and follow-up in the IMD Clinic in the Service of Genetics and Metabolism and in the Service of Endocrinology, both located in the HNN. The diagnostic confirmation of the IMDs PKU, MSD and galactosemia, are carried out in the High Risk Section of the Central Screening Laboratory. The diagnostic confirmation of $\mathrm{CH}$ and $\mathrm{CAH}$, is carried out in the Hormones Section of the Clinical Laboratory at the same Hospital.

\section{Quality control}

The centralization of the tests in a single laboratory is an essential requirement proven in its effectiveness for in any MNS program. In addition to the prohibitive cost of having specialized teams and expensive equipment in different laboratories, the obvious necessary strict quality control in this type of program, can only be properly established in a central laboratory, in this case only one for the whole country. This set up makes it possible for our Laboratory to be conveniently affiliated, since 1992, so far with optimal results, to the Program of Quality Assurance of the Centers for Disease Control and Prevention in Atlanta, Georgia, USA.

One of the main concerns in any screening program is to limit to a minimum the need to call a family in order to confirm a positive result in the initial sample. In table 3 it is observed that the percentage of false positives for $\mathrm{CH}, \mathrm{PKU}$ and MSD has been maintained at reasonable levels, with figures very close to those reported in well established MNS programs in developed countries (Levy et al. 2000). As for the CAH and Galactosemias, of recent introduction to the Program, the percentage of false positives has been relatively high. However, it is expected that these figures improve with time, which we are already observing in the case of the CAH where the figure for false positives in 2003 is $0.01 \%$.

TABLE 3

Percentage of false positives and false negatives for each disease and laboratory method applied

$\begin{array}{lccc}\text { Disease } & \text { Methods } & \text { False Positives } & \text { False Negatives } \\ \text { Congenital Hypothyroidism } & \text { IFMA* } & 0.01 \% & 0.0004 \% \\ \text { Phenylketonuria } & \text { BIA } & 0.01 \% & 0.0 \% \\ \text { Maple Syrup Disease } & \text { BIA } & 0.007 \% & 0.0 \% \\ \text { Galactosemia } & \text { IFMA } & 0.08 \% & 0.0 \% \\ \text { Congenital Adrenal Hyperplasia } & \text { IFMA } & 0.01 \% & 0.0 \%\end{array}$

\footnotetext{
* Abbreviations in text
} 
It is generally possible to carry out the confirmation or exclusion of a specific diagnosis in a maximum of three days, most of the times one to two days after the family is notified of a positive result in the initial sample.

In the almost fifteen years of operation of the PNT, after 835217 newborns screened, only three cases of false negatives for $\mathrm{CH}$ have been observed. The first one in 1996 was due to a problem with the laboratory technique, added to the inexperience of the Program regarding the follow up of ambiguous samples. The second case in 1998 was due to a clerical error. The third case was due to a problem with the laboratory technique. According to wide experience in programs of other countries, the frequency of false negatives for $\mathrm{CH}$ is for 1 each 100000 screened children (AAP 1993).

The drawing of blood from the child's heel, although relatively simple, requires dexterity in order to achieve that the blood, more viscous in the neonate that in older children, flows appropriately. It is important to point out that for each child a disposable lancet is used with a mechanism that limits the depth of the puncture. We have made efforts to train the health personnel involved in pediatrics, in the proper blood drawing technique. To further facilitate the procedure, detailed instructions on how to carry out the process are printed in the reverse of the form for the child's data. It is our goal to significantly decrease the need to request a second sample due to an inadequate initial sample (scattered blood, one or more drops on top of the first one, etc.) with consequent discomfort for the child and family and waste of time. Figure 2 shows the evolution of the annual percentage of inadequate samples. We are in the process of further reducing the lowest figure of $1.4 \%$ reached in the year 2001 . The introduction of two diseases in January 2002, CAH and the galactosemias, plus the inclusion of another twelve diseases in June of this year, however, has demanded additional disks to be perforated from the DBS, which intensifies the requirement for a sample to qualify as satisfactory.

\section{EVOLUTION OF THE NEONATAL SCREENING PROGRAM}

The evolution of the newborn screening coverage after 14 years 6 months of official and uninterrupted operation of the PNT, is shown in figure 3. In the year 1990 the coverage was very low due to the requisite of asking the primary health care personnel for a new task, the drawing of the sample, registration of the child's and mother's data as well as the

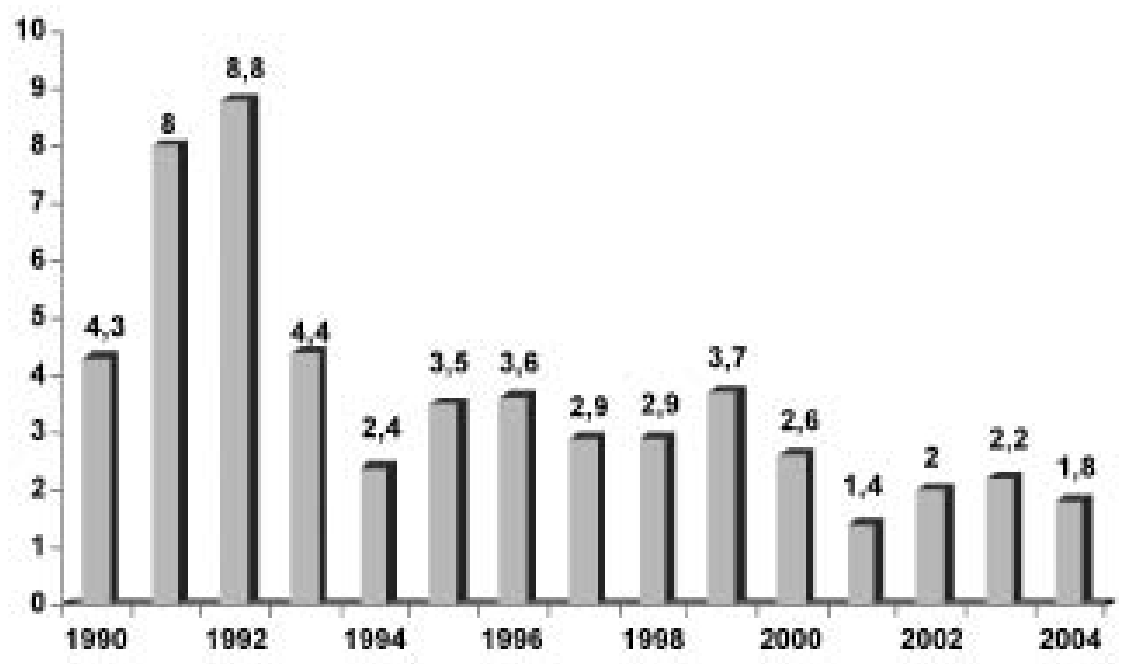

Fig. 2. Evolution of inadequate samples. National Neonatal Screening Program, Costa Rica. 


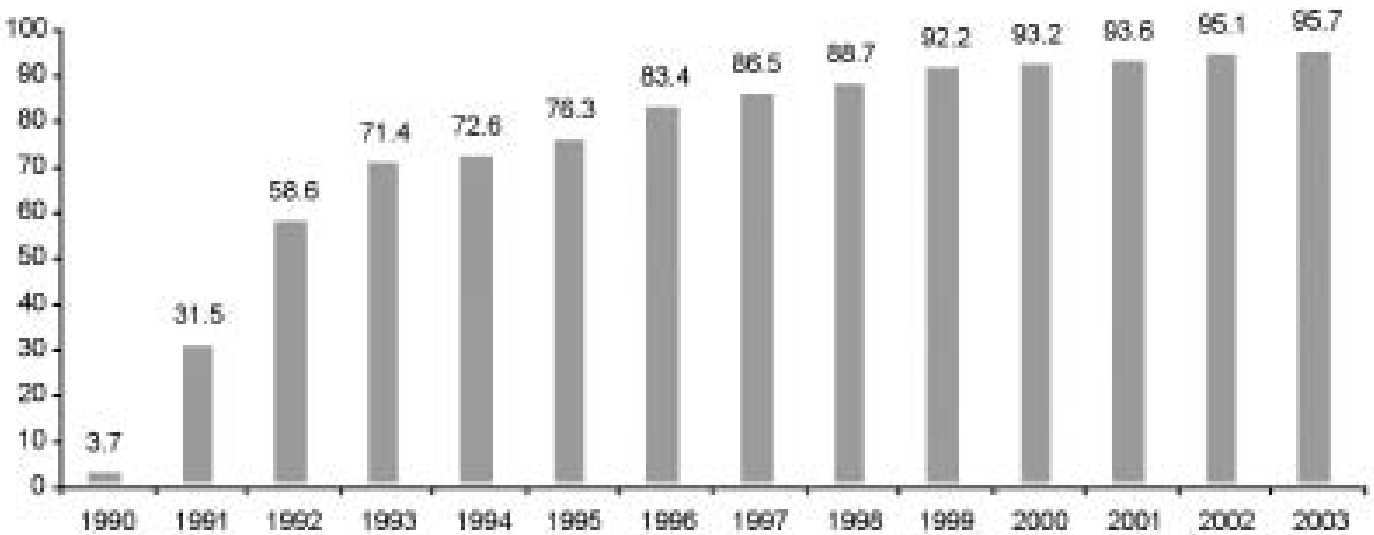

Fig. 3. Coverage 1990-2003. National Neonatal Screening Program, Costa Rica.

location of the patient when the result was positive. Bureaucracy was an intimidating obstacle to be overcome during this initial period. In subsequent years the increase in coverage progressed relatively fast, to $95.7 \%$ in December, 2003. To the end of September of 2004, 835 217 newborns had been screened.

One of the program's mid-term goals is to take advantage of the mass media communication and be able to achieve 100 percent coverage, or at least reach coverage close to this ideal.

TABLE 4

Cases detected, confirmed and treated National Neonatal Screening Program, Costa Rica. March 1990-September 2004

Total Newborns Screened

835217

Disease

\# of cases

Congenital Hypothyroidism

259

Phenylketonuria

18

Maple Syrup Disease

Congenital Adrenal Hyperplasia*

20

30

10

Galactosemia

3

Propionic Acidemia**

Medium Chain Acyl-CoA Dehydrogenase Deficiency**

Total

*Pilot Study 1999-2000. Starts massive screening: January 2002. Newborns screened: 329529.

** Starts massive screening: June, 2004. Newborns screened: 18000 .
The total of cases detected, confirmed and treated in the 14 years 6 months of operation of the PNT, is shown, for each disease, is shown in Table 4.

All of the affected children immediately receive the specific treatment for the given disease. Follow up is done in periodic ambulatory consultations in the Services of Genetics and Metabolism and of Endocrinology of the HNN. Practically all the children treated evolve satisfactorily. The patients with MSD represent an extraordinary challenge due to the severity of the clinical picture that they generally present in the first days of life; in their follow up, some of these cases show certain degree of retardation in the psychomotor development.

If we make an estimate of the frequency of diseases found to September 2004, we observe that the figure for $\mathrm{CH}$ of 1:3224 is similar to the one reported in other countries (Levy et al. 2000). On the other hand, there is apparently a relatively low frequency for PKU 1:46400. In this regard it is sad to point out that the last two infants where detected belatedly with PKU in 2002 were due to the fact that the parents unfortunately decided not to take them for the screening test, at a time when the PNT was already in operation. However, no new cases have been detected since then. The relative high frequency of MSUD 1:41760 could be related to the relatively high frequency of this 
disease reported in Spanish populations (Ugarte 1983). We have observed an average of two cases per year since the program began screening for MSUD in 1999.

We can make early estimates of the frequency for the diseases of recent introduction to the PNT since January 2002. The finding of 30 cases of $\mathrm{CAH}$, for a frequency of $1 / 6604$ during this short period, is probably a reflection of the apparent high frequency of this disease long observed at the clinical level in the HNN (Artavia et al. 1993). It is surprising to observe an apparent high frequency of galactosemia 1:9907 in our newborn population. Of the ten cases detected, 3 have shown diminished GALT activity, which corresponds to the classic form of this disease, and 6 showed normal activity for GALT. No enzyme studies have yet been done for one of the patients (Abarca et al. 2003). These data have to be compared with the clinical observation, before neonatal screening, in our IMD clinic where, during approximately 25 years, there had only been 2 cases apparently with the classic form of galactosemia, in comparison to 11 cases of galactokinase deficiency (Casco et al. 1996), this showing a better response to treatment which in turn motivated the inclusion of the galactose determination in the DBS. It is important to point out that of the 11 GALK deficient patients, 10 had to be intervened surgically due to bilateral cataracts (vide infra).

\section{Expansion of the national neonatal screening program}

The expansion of massive screening to short and medium term is carried out by means of pilot studies for the following diseases or groups of diseases:

A pilot study for cystic fibrosis has begun which includes the determination of the immunoreactive trypsinogen (IRT) in samples of children being screened in the PNT. Prevalent mutations in the Cystic Fibrosis Transmembrane Regulator (CFTR) gene from patients formerly diagnosed with cystic fibrosis in the Neumology Service of the HNN are being identified by DNA analysis.
We are in the design stage and financing search for pilot projects aimed at the introduction of abnormal hemoglobinopathies and eventually of toxoplasmosis in massive neonatal screening.

Homocystinuria is at the moment part of the high risk screening in the PNT. There is controversy in different programs around the world regarding the justification of including this disease in massive screening. Other diseases being considered to be included in the long term in the PNT, given the required resources, are Biotinidase deficiency, Acquired Immunodeficiency Syndrome (AIDS), and Congenital Deafness.

\section{HIGH RISK SCREENING}

Some IMDs are not included in massive neonatal screening because they still have no effective treatment, or because appropriate methodology is not yet available, can only be detected following the clinical suspicion or family background (High Risk Screening). For this reason we continue carrying out simple and non expensive biochemical laboratory techniques such as the classic "metabolic tests" and paper and thin layer chromatography of amino acids and sugars used for nearly 30 years in the HNN. The IMD included in the high risk screening in our program include Homocystinuria, Cystinuria, Tyrosinemia, Urea Cycle Disorders, Non ketotic Hiperglycinemia, Hartnup disease, Fanconi syndrome (Cystinosis), Hereditary Fructose Intolerance, the Mucopolysacaridosis and Lesh-Nyhan syndrome, as well as hereditary disorders of lipoprotein metabolism.

The work carried out by our group in high risk screening and clinical aspects of IMDs has been published in international and national journals as well as presented in national and international meetings (Velázquez et al. 1988, de Céspedes 1979, de Céspedes et al. 1983a, Pérez et al. 1985).

Basic clinical research and experimental studies in animals, aimed to better characterize 
some of these diseases as well as to improve the so far limited possibilities for their treatment, have been done in collaboration with groups in USA universities. One of the diseases studied so far is propionic acidemia which is one of the IMDs most frequently presented in our Hospital (Sweetman et al. 1978). This study was performed using a family with several affected siblings; it clearly demonstrated a response to biotin, the cofactor in the defective enzyme, propionyl-CoA-carboxylase. At the time there was only one previous report of a similar finding (de Céspedes et al. 1977, 1978).

DNA analysis has been productive in the identification of prevalent mutations in the phenylalanine hydroxylase gene in some of our PKU patients (Santos et al. 1996).

DNA analysis of the GALK gene in most of our GALK deficiency patients previously mentioned (Casco et al. 1996), showed a high genetic homogeneity, with a prevalence of a single mutation, present in the homozygote form in most of the patients studied (Kolosha et al. 2000). This remarkable genetic homogeneity opens the possibility to reinforce the neonatal screening with DNA analysis as a backup test. DNA analysis so far has limited application in massive neonatal screening (Zhang et al. 1994).

Experimental studies in rats have been directed towards transport mechanisms in cellular membranes which could explain alterations found in the distribution of amino acids, observed in patients with PKU and MSD. The concentration pattern of amino acids observed in non treated PKU patients was very closely reproduced for the first time, as far as we know, in animals. The findings of transport effects in non brain tissues, fundamentally skeletal muscle (de Céspedes et al. 1989, 1992), practically neglected in similar studies that so far only contemplate the brain, although they do not have immediate clinical application, could serve as a base for therapeutic interventions that may improve the treatment of patients with PKU or MSUD.

\section{COSTA RICAN ASSOCIATION FOR SCREENING AND PREVENTION OF DISABILITIES IN CHILDREN}

Due to high financial debt, the Costa Rican government adopted a restrictive policy of new appointments in public institutions, to such a degree of inflexibility that it was practically impossible to create the positions required for the technical personnel needed at the PNT. A legal way to go around this hold back was the creation in 1993, of the Costa Rican Association for Screening and Prevention of Disabilities in Children (ASTA) formed fundamentally by the same professionals involved in the PNT and by patients' families (ASTA won the 2002 Reina Sofia Award of Prevention of Disabilities, Madrid, Spain). ASTA is a non-profit private association, officially acknowledged for Social Welfare and for Public Utility. The CCSS buys Laboratory services to ASTA which in turn hires about $85 \%$ of the personnel of the PNT. The other $15 \%$ refers to the old personnel who worked for the old Biochemical Laboratory with high risk screening and diagnoses that were just transferred, as well as the clinicians of the Genetics and Metabolism Services. The responsibility of the Association with the PNT has increased; in 1998 the Ministry of Health assigned the administration of the Screening Central Laboratory to ASTA. The presence of ASTA has attracted and made possible donations from public institutions such as the Board of Social Protection as well as from the private sector.

The Board of Directors for the period March 2003 - March 2005 is conformed as follows: Carlos de Céspedes -Montealegre (President), Manuel Saborío-Rocafort (Vicepresident), Alvis Gonzalez-Garita (Secretary), Rafael TrejosMontero (Treasurer), Emilia Solís-Díaz (Vocal), and Juvenal Feoli-Fonseca (Fiscal).

The aims of ASTA as contemplated in its Constituent Records are: (1) Promote and look after the development and the maintenance of neonatal and high risk screening in Costa Rica with the aim of preventing mental retardation 
and other disabilities in children. (2) Assemble competent professionals interested in screening. (3) Gather together families of patients and members of the community interested in screening. (4) Promote and support the training of technicians and professionals in the different steps of screening, and (5) Promote and support scientific research, applied to the continuous improvement of screening.

The activities of ASTA are: (1) Motivate the support of institutions from the Health Sector and of other public institutions as well as from the private sector, for the achievement of its objectives. (2) Capture and administer funds coming from donations contributed by national or foreign entities, dedicated to the realization of the objectives of the Association.

(3) The Association could acquire all kinds of goods, always under the limitations of the article forty three of the Civil Code, to celebrate contracts of all nature and to carry out all kinds of licit operations which help in the achievement of its aims. (4) Organize formative and informative activities such as seminars, conferences, round tables, courses and other events related to screening. (5) Name a member representative of the Association before the Technical Council of Neonatal Screening.

\section{CENTER FOR PREVENTION OF DISABILITIES}

The success of the PNT demonstrates that it is possible, even in a developing country such as Costa Rica, to implement preventive actions and to address effectively the enormous challenges that the new epidemical profile imposes. It also encourages us, albeit with caution, to apply screening to a growing number of diseases.

It is important to note the dedication and devotion of the professionals and the technicians involved in the PNT, for almost 15 years now, mainly those of the Central Screening Laboratory, who have been forced to move three times, due to a lack of permanent physical headquarters.
The moral obligation to expand and optimize the PNT spurred the idea of developing an ambitious project with futuristic vision: the Center for Prevention of Disabilities (CPD), a combined effort of the CCSS through the HNN and ASTA, with the economic support of the Board of Social Protection of San Jose, the Active Club 20-30 and the Telethon, with additional aid from the private sector and international organizations.

The CPD started its function on September 23, 2002 in a modern building, designed and built strictly following the current and future needs of the PNT. The idea of the CPD is expressed in the following objectives and aims.

The task of CPD are: (1) Diminish the moral and economic cost of disabilities preventable through screening. (2) Improve continuously the human side of screening. (3) Carry out analyses and evaluations directed to the progressive expanding and continuous optimization of the prevention of disease through screening. (4) Carry out scientific research based upon and applied to the prevention of disabilities caused by chronic diseases in collaboration with peer groups in universities and other institutions at national and international levels.

The CPD is a door that Costa Rican health system opens to the medicine of the XXIst century, individualized, predictive and preventive, based on the identification through screening of risk of disabilities and eventually prevention of the development of the disease itself. The aims of CPD include: (1) Create a Center for the selective implementation in Costa Rica of the findings of the Human Genome Project to health - Applied Genomics. (2) Create a Center for education and training for professionals, technicians and the population in the prevention of disabilities and chronic diseases. (3) Have a Center attentive to the bioethical issues inherent to the application of the advances of the genetic revolution to medicine-primun non nocere.

It is important to point out certain characteristics of the CPD that allow to envision a 
higher efficiency and effectiveness of the PNT in all of its components, that is, detection, diagnosis, treatment, follow up and genetic counseling: It offers the appropriate conditions for the integration of the Neonatal Screening Laboratory with the High Risk Screening Laboratory into a single laboratory: the National Laboratory of Neonatal and High Risk Screening or Central Screening Laboratory. The detection and diagnostic confirmation of IMD cases is now carried out in that integrated laboratory. Physicians and allied health professionals (nutritionist, social worker) of the Service of Genetics and Metabolism are now incorporated in the new building of the CPD. The CPD is integrated organizationally and physically to the HNN, which allows a valuable feedback for the Central Screening Laboratory with the specialized clinics for treatment, genetic advice and follow up of affected children detected by screening not only for the diseases included in the PNT at the moment, but also those that are to be added in the future. The Informatics Section of the CPD will allow the organization of a database to be fed with valuable information systematically obtained during the entire screening process. This resource is fundamental in the optimization of the PNT. Also, specific research projects may very well spin off from this process, thus producing useful information to establish pertinent policies in other areas of public health. For example, taking advantage of the available data of the newborn and the mother, such as birth weight, gestational age, etc., the realization of epidemiologic studies is practically straightforward.

In the future, given favorable political and economic conditions, the CPD would be in a position to extend its action to a regional level, especially Central America and the Caribbean.

\section{RESUMEN}

Presentamos la evolución, organización y los resultados del Programa Nacional de Tamizaje Neonatal y de Alto Riesgo en Costa Rica (PNT). Este programa ha estado trabajando ininterrumpidamente por más de catorce años.
Actualmente Costa Rica tiene una tasa de alfabetización del $95 \%$. En agosto de 2004 la tasa de mortalidad infantil fue de 9.74 por 1000 nacimientos y en el 2003, la expectativa de vida era de 76.3 años para hombres y de 81.1 para mujeres. El control de las enfermedades infecciosas y parasíticas, así como de la malnutrición severa, ha dado lugar a la prevalencia de enfermedades crónicas con un perfil patológico similar a los de los países desarrollados. La observación clínica, principalmente iniciando desde los años 70, de un número creciente de pacientes con retardo mental y otras discapacidades causadas por hipotiroidismo congénito y enfermedades metabólicas hereditarias que podrían haber sido prevenidas en muchos casos con un diagnóstico temprano y un tratamiento oportuno, nos llevo a tomar la decisión de implementar un sistema de tamizaje neonatal masivo para estas enfermedades. La presencia de un sistema público de seguridad social en Costa Rica, el cual actualmente incluye desde la atención primaria de la salud hasta la atención terciaria en los hospitales, con un único Hospital de Niños para todo el país, así como las facilidades de comunicación, son factores que ofrecen, en principio, condiciones favorables para este esfuerzo, aun en un país subdesarrollado. De esta manera, luego de un Decreto Ejectutivo, el PNT empezó en marzo de 1990. Las enfermedades incluidas desde el principio consistían del hipotiroidismo congénito, fenilcetonuria, y jarabe de arce. La hiperplasia adrenal congénita y la galactosemia fueron incluidas en enero de 2002 después de un programa piloto (1999-2000). Para setiembre de 2004 han sido tamizados 835217 niños. Hay una cobertura del $95.1 \%$ de los nacimientos del país. También para esta fecha, han sido detectados, confirmados y tratados 259 niños con hipotiroidismo congénito, 18 con fenilcetonuria, 20 con jarabe de arce, 30 con hiperplasia adrenal congénita y 10 con galactosemia; para un total de 337 niños que fueron salvados del retardo mental, otras discapacidades o incluso de la muerte. Además de las enfermedades antes mencionadas, y después de un proceso inicial de tamizaje del alto riesgo, y diagnóstico de acidemias orgánicas por espectrometría de masas en tandem (MS/MS), el tamizaje masivo neonatal de este tipo de enfermedades empezó recientemente en junio de 2004. Se han encontrado 3 casos de acidemia propiónica y 2 casos de Deficiencia de AcilCoA deshidrogenasa de cadena media (MCAO). Un estudio piloto ha empezado para el tamizaje de la fibrosis quística; y esperamos que las hemoglobinopatías y la toxoplasmosis de sumen a la lista en un futuro próximo. El Centro de Prevención de Discapacidades del Hospital Nacional de Niños "Dr. Carlos Sáenz Herrera", fue diseñado y construido en función de las necesidades de optimización y amplificación del tamizaje en Costa Rica. En este Centro fue posible integrar convenientemente el tamizaje neonatal, el tamizaje de alto riesgo, y la confirmación del diagnóstico de las enfermedades ahora incluidas en el programa nacional, así como de las que se adicionen en el futuro. La combinación física y organizacional con los correspondientes servicios clínicos especializados del Hospital también facilita el cumplimiento de los objetivos 
fundamentales del tamizaje, principalmente la detección y tratamiento oportunos de los niños afectados. El Centro de Prevención de Discapacidades, que empezó a funcionar en setiembre de 2002, también representa una puerta que abre el sistema de salud costarricense a la práctica de la medicina del siglo 21 y a la genómica aplicada.

\section{REFERENCES}

Abarca, G., R. Trejos, A. Sánchez, A. Reuben, C. de Céspedes, C. Vargas \& M. Saborío. 2003. Experiencia del Tamizaje Neonatal de Galactosemia en Costa Rica: Diciembre 2001- Junio 2003. IV Congreso Latinoamericano de Errores Innatos del Metabolismo y Pesquisa Neonatal - 2003, Cataratas del Iguazú, Misiones, Argentina, Octubre 26-29.

American Academy of Pediatrics. 1993. Newborn Screening for Congenital Hypothyroidism: Recommended Guidelines (RE9316). Pediatrics 91: 1203-1209.

American Academy of Pediatrics. 2000. Serving the Family from Birth to the Medical Home. A report from the Newborn Screening Task Force. Pediatrics. 106(Suppl.): 379-427.

Anonymous. 2001. Memorias del III Congreso Latinoamericano de Errores Innatos del Metabolismo y Pesquisa Neonatal. Cartagena, Colombia. Octubre 21-24.

Artavia, E. \& M.L. Agüero. 1993. Classical congenital adrenal hyperplasia due to 21 hydroxylase deficiency in Costa Rica: Estimated incidence by case survey. $9^{\text {th }}$ International Neonatal Screening Symposium \& $2^{\text {nd }}$ Meeting of the International Society for Neonatal Screening. Lile, France, September 13-17.

AutoDELFIA (TM). Neonatal hTSH. Wallac Oy, Turku, Finland.

AutoDELFIA(TM). Neonatal 17 $\alpha-\mathrm{H}$-progesterone. Wallac Oy, Turku, Finland.

Bulyzhenkov, V. 1991. Prevention and control of phenylketonuria. WHO Bulletin. 69: 367-368.

Casco, T, M. Saborío, R. Trejos \& C. de Céspedes. 1996. Galactokinase deficiency in eleven patients from eight Costa Rican families: Clinical and biochemical features (Poster). Annual Meeting of the Society for Inherited Metabolic Disorders, Cocoyoc, Morelos, México, marzo 5-7.

Casco, T, R. Trejos, E. Artavia, M. Saborío, G. Abarca, A. Sánchez \& C. de Céspedes, 1999. Programa de Tamizaje Neonatal en Costa Rica. II Congreso Latinoamericano de Errores Innatos del Metabolismo y Pesquisa Neonatal. Santiago, Chile, octubre 24-27.
CCSS. 2000-2006. Plan de atención a la salud de las personas. Caja Costarricense de Seguro Social, pg. 143.

Collins, F.S. 1999. Shattuck lecture. Medical and societal consequences of the human genome project. N. Engl. J. Med. 341: 28-37.

Chavarría, S. \& C. de Céspedes, 1981. Estudio costo/beneficio de la detección neonatal del hipotiroidismo y la fenilcetonuria en Costa Rica. I Congreso Centroamericano de Endocrinología y Metabolismo, San José, Costa Rica, noviembre.

de Céspedes, C., A.R. Loría, Y. Estrada, L. Sweetman \& W.1. Nyhan. 1977. The diagnosis and management of propionic acidemia. Hum. Hered. 27: 169

de Céspedes, C., A.R. Loría, Y. Estrada, L. Sweetman \& W.L. Nyhan. 1978. The diagnosis and management of propionic acidemia. Mongr. Hum. Genet. 9: 80-83.

de Céspedes, C. 1979. Errores Congénitos del Metabolismo. Edición Extraordinaria. Rev. Med. Hosp. Nal. Niños (Costa Rica): 207-220.

de Céspedes, C., I. Santiesteban I, D. Ortiz, E. Rojas E, J. Rodríguez, C. Nanne \& J. Orlich. 1983a. Patrones de excreción de aminoácidos urinarios en niños excepcionales y pacientes con trastornos mentales en Costa Rica. Rev. Biol. Trop. 31: 1-9 .

de Céspedes, C., I. Santiesteban, D. Ortiz \& E. Rojas. 1983b. On the organization of neonatal screening for hypothyroidism and inborn errors of metabolism in Costa Rica. In H. Naruse (ed.). Neonatal Screening. Ecxerpta Medica. International Congress Series \# 606, Amsterdam.

de Céspedes, C., I. Santiesteban, E. Rojas \& D. Ortiz. 1984. Detección de fenilcetonuria y otros errores congénitos del metabolismo en Escuelas de Enseñanza Especial de Costa Rica. Rev. Cost. Cienc. Med. 5: 17-25.

de Céspedes, C. 1986. Problems in Implementing newborn screening in Costa Rica. 6th International Neonatal Screening Symposium and 5th National Neonatal Screening Symposium, Austin, Texas, November.

de Céspedes, C., J.G. Thoene, K. Lowler \& H.M. Christensen. 1989. Evidence of inhibition of exodus of small neutral amino acids in non brain tissues of hyperphenylalaninemic rats. J. Inher. Met . Dis. 12: 166-180.

de Céspedes, C. 1991 Nutrición en Costa Rica. Cuadernos de Nutrición, México 14: 33-37.

de Céspedes, C, J.G. Thoene, K. Lowler \& H.N. Christensen. 1992. Leucine and tissue distribution of bulky and small neutral amino acids in rats: Dissociation between transport and insulin-mediated effects. J. Inher. Met. Dis. 15: 145-154. 
de Céspedes, C., R. Trejos, L. Umaña, E. Artavia, T. Casco, S. Rodríguez \& L. Cunninghan. 1995a. Nationwide Neonatal Screening for congenital hypothyroidism, phenylketonuria and maple syrup urine disease in Costa Rica. Abstract 0-2, pág. 17. 11th National Neonatal Screening Symposium, Corpus Christi, Texas, setiembre 25-30, 1994 (Abstract selected in Infant Screening Newsletter of the ISNS, 1995. 18: 12.

de Céspedes, C., R. Trejos, L. Umaña, E. Artavia, T. Casco, S. Rodríguez \& L. Cunningham. 1995b. Programa nacional de tamizaje neonatal masivo de hipotiroidismo congénito y enfermedades metabólicas hereditarias en Costa Rica. V Congreso Nacional de Salud Pública, San José, Costa Rica, setiembre.

de Céspedes, C., R. Trejos, L. Umaña, E. Artavia, T. Casco, S. Rodríguez S \& L. Cunningham. 1996a. Tamizaje neonatal masivo de hipotiroidismo congénito y enfermedades metabólicas hereditarias en Costa Rica: 1990-1995. Rev. Cost. Salud Pública. 5: 1-2.

de Céspedes, C., L. Umaña, I. Yock, M. Bustamante \& T.L Atkins. 1996b. Frecuencia y demanda de atención médica de las enfermedades genéticas en el Hospital Nacional de Niños "Dr. Carlos Sáenz Herrera". Acta Ped. Cost. 10: 53-60.

Dodge, JA. 1999. Why Screen for Cystic Fibrosis? A clinician's view. Acta Paediatr. 432(Suppl.): 28-32.

Downie, R.S, C. Tannahill \& A. Tannahi (eds.). 1966. Health Promotion. Models and Values. Oxford University, p 50.

Dussault, J.H., P. Coulombe, C. Laberge, J. Letarte, H. Guyda \& K. Khoury. 1975. Preliminary report on a mass screening program for neonatal hypothyroidism. J. Pediatr. 86: 670-674.

Estado de la Nación. 2001. En desarrollo humano sostenible. Proyecto Estado de la Nación. $N^{\circ}$ 8. Editorama, Costa Rica.

Guthrie, R. 1961. Blood screening for phenylketonuria. JAMA 178: 863.

Guthrie, R. \& A. Susi. 1963. A simple phenylalanine method for detecting phenylketonuria in large populations of newborn infants. Pediatrics 32: 338-343.

Guttmacher, A.E. \& F.S. Collins. 2002. Genomic Medicine - A Primer. N. Engl. J. Med. 347: 1512-1520.

INEC. 2004. Statistical Data for Costa Rican Population.
Kaback, M.M. 2001. The Asilomar Process and the Human Genome Project. Perspect Biol. Med. 44: 230-234.

Kolosha, V., E. Anoia, C. de Céspedes, R. Gitzelman, L. Shih, T. Casco, M. Saborío, R. Trejos, N. Buist, T. Tedesco, W. Skach, O Mitelman, D. Ledee, K. Huang \& D. Stambolian. 2000 Novel mutations in 13 probands with galactokinase deficiency. Hum. Mut. 15: 447-453.

Levy, H.L. 1998. Newborn screening by tandem mass spectrometry: a new era. Clin Chem.44: 2401-2402.

Levy, H.L. \& S. Albers. 2000. Genetic Screening of Newborns. In E. Lander, D. Page, R. Lifton. (eds.). Ann. Rev. Genom. Hum. Genet. Palo Alto, CA.

Neonatal Total Galactose Test Kit. PerkinElmer Life Sciences Inc., Norton, OH, USA.

Pérez, VH, A. Baltodano, C. de Céspedes \& R. Trejos. 1985. Enfermedad de la orina del jarabe de arce en Costa Rica. VI Congreso Nacional de Pediatría. San José, Costa Rica, noviembre.

Santos, M., AL. Kuzmin, RC. Eisensmith, A. Goltsov, SLC. Woo, R. Barrantes \& C. de Céspedes. 1996. Phenylketonuria in Costa Rica: Preliminary spectrum of PAH., mutations and their association with highly polymorphic haplotypes. Hum. Hered. 46: 128-131.

Scriver, CR, C. Laberge, CL. Clow, et al. 1980. Genetics and Medicine: An evolving relationship. Science 200: 946-952.

Sweetman, L, W. Weyler, WL Nyhan, C. de Céspedes, A.R. Loría \& Y. Estrada. 1978 Abnormal metabolites of isoleucine in a patient with propionyl-CoA carboxylase deficiency. Biomed. Mass. Spectr. 3: 198.

Ugarte, M. 1983. Spanish group for the study of inborn errors of metabolism. Neonatal screening programme for aminoacid disorders and congenital hypothyroidism in Spain. In H. Naruse (ed.). Neonatal Screening. Ecxerpta Medica. International Congress Series \# 606, Amsterdam, pp. 491-492.

Velázquez, A, C. de Céspedes, D.C. DeVivo, G. Costin \& K.N.F Shaw. 1988 Hepatic metabolites and uric acid excretion in fructose-1,6-diphosphatase deficiency. J. Inher. Metab. Dis. 11: 303-304.

Zhang, Y.H., LL. McCabe, M. Wilborn, BL. Therrell \& ER. McCabe. 1994. Application of molecular genetics in Public Health: improved follow up in a neonatal hemoglobinopathy screening program. Biochem. Med. Metab. Biol. 52: 27-35. 